\title{
Influence of adipocyte size and adipose depot on the number of adipose tissue macrophages and the expression of adipokines in dairy cows at the end of pregnancy
}

\author{
E. Depreester, ${ }^{* 1}$ J. De Koster, $\dagger^{1,2}$ M. Van Poucke,‡ M. Hostens, ${ }^{*}$ W. Van den Broeck,§ L. Peelman, $\ddagger$ \\ G. A. Contreras,t and G. Opsomer* \\ *Department of Reproduction, Obstetrics and Herd Health, Faculty of Veterinary Medicine, Ghent University, Salisburylaan 133, 9820 Merelbeke, \\ Belgium \\ †Department of Large Animal Clinical Sciences, Michigan State University, 736 Wilson Road, East Lansing 48824 \\ ‡Department of Nutrition, Genetics and Ethology, Faculty of Veterinary Medicine, Ghent University, Heidestraat 19, 9820 Merelbeke, Belgium \\ §Department of Morphology, Faculty of Veterinary Medicine, Ghent University, Salisburylaan 133, 9820 Merelbeke, Belgium
}

\begin{abstract}
The aim of this study was to determine the number of adipose tissue macrophages (ATM) and the mRNA expression of adipokines [adiponectin $(A D I P O Q)$, leptin $(L E P)$, interleukin 6 (IL6), tumor necrosis factor $(T N F)$, and interleukin 10 (IL10)] in different adipose depots from cows with a variable body condition score (BCS) at the end of the dry period. We hypothesized that the number of ATM and the expression of these adipokines depend on adipocyte size and the anatomical location of the adipose depot. Subcutaneous, omental, mesenteric, perirenal, and intrapelvic adipose tissue samples were taken immediately after euthanasia of 10 Holstein Friesian dairy cows (upcoming parity 2 to 5, age $3.9 \pm 1.4 \mathrm{yr}$; mean \pm standard deviation) at the end of pregnancy (actual days of pregnancy at the moment of euthanasia: $269 \pm 5 \mathrm{~d}$ ). During the dry period, all animals received similar diets to meet but not exceed requirements. Five animals were considered to have a normal BCS (2.5-3.5) and 5 animals were considered to be over-conditioned $(\mathrm{BCS}=3.75-5)$. Body weight of the animals at the moment of euthanasia was 717 $\pm 77 \mathrm{~kg}$. Expression of the different genes was determined by reverse transcription quantitative real-time PCR. Adipocyte size was determined by measuring the area of 100 adipocytes on histological sections. Average adipocyte area was $10,475 \pm 1,019,8,500 \pm$ $780,10,383 \pm 1,227,11,466 \pm 1,039$, and 11,087 \pm $1,632 \mu \mathrm{m}^{2}$ for the subcutaneous, mesenteric, omental, intrapelvic, and perirenal adipose depot, respectively.
\end{abstract}

Received September 1, 2017.

Accepted February 28, 2018.

${ }^{1}$ These authors contributed equally to this work.

${ }^{2}$ Corresponding author: dekoste2@msu.edu
Immunohistochemistry using anti-bovine CD172a antibodies was performed to determine the proportion of ATM (the number of CD172a-positive cells per 100 adipocytes, given as a percentage). Expression of $L E P$, $I L 6$, and $T N F$ was positively associated with adipocyte size, whereas no association could be detected between $A D I P O Q$ and IL10 with the size of the adipocytes. The omental adipose depot was especially infiltrated with $\operatorname{ATM}(1.92 \pm 0.55,1.10 \pm 0.33$, and $8.28 \pm 2.24 \%$ for the subcutaneous, mesenteric, and omental adipose depot, respectively). The proportion of ATM was positively associated with the size of the adipocytes in the omental and mesenteric adipose depot. Expression of $A D I P O Q, L E P, I L 6, T N F$, and IL10 differed among depots, which suggests differences in inflammatory characteristics depending on the anatomical location of depots. In conclusion, the results of the present study confirm the adipose tissue as a potential source of inflammatory mediators and demonstrate ATM infiltration, especially in the omental adipose depot.

Key words: adipokine, adipose tissue, adipose tissue macrophage, mRNA expression

\section{INTRODUCTION}

Important physiological changes occur during the transition period of dairy cows, being the last $3 \mathrm{wk}$ before calving and the first 3 wk of lactation (Drackley, 1999). Despite much progress made regarding the metabolism of dairy cows during the transition period, 30 to $50 \%$ of the dairy cows suffer from 1 or more health disorders in the transition period (LeBlanc, 2010). Multiple risk factors have been identified in the development of transition cow disorders, among which excessive mobilization of body fat is well characterized (Drackley, 1999; McArt et al., 2013; Roche et al., 2013). Recent research indicates that a dysregulation of inflammatory processes in the periparturient dairy cow 
may contribute to the development of infectious and metabolic disorders (Trevisi et al., 2012; Bradford et al., 2015; Sordillo, 2016). Different underlying reasons exist for the dysregulation of inflammatory processes, which have been reviewed by Sordillo and Raphael (2013) and Bradford et al. (2015).

Adipose tissue is considered to have a causative role in the dysregulation of inflammatory processes (Drackley et al., 2005; Loor et al., 2007; Contreras et al., 2017). In humans, obesity is associated with a chronic proinflammatory state, known as a metabolically triggered inflammation or metaflammation (Hotamisligil, 2006). In the obese state, macrophages infiltrate the adipose tissue, triggering an inflammatory response that is considered a risk factor for the development of insulin resistance, type-2 diabetes mellitus, and cardiovascular disease (Després and Lemieux, 2006; Cornier et al., 2008). The excessive accumulation of abdominal or visceral fat is considered to be especially detrimental for humans, due to metabolic and functional differences between the subcutaneous and abdominal adipose depot (Després and Lemieux, 2006). Large visceral adipocytes demonstrate a higher lipolytic activity, lower insulin sensitivity, and a dysregulated production of adipokines characterized by higher pro- and lower anti-inflammatory levels of adipokines (Després and Lemieux, 2006). Over-conditioned dairy cows are known to be at an increased risk for the development of different transition problems; this is, in the first place, due to excessive release of free fatty acids from the adipose tissue in the immediate postpartum period (Roche et al., 2009). However, it is not known if high lipolysis rates in over-conditioned cows leads to inflammatory responses that trigger adipose tissue macrophage (ATM) infiltration and dysregulated production of adipokines. Recent research indicates that overfeeding energy in nonpregnant and nonlactating dairy cows changes the adipose transcriptome, characterized by increased expression of lipogenic genes and increased expression of genes involved in inflammatory pathways. The transcriptome of mesenteric adipose tissue was altered by the energy level compared with subcutaneous adipose tissue (Moisá et al., 2017).

The aim of the present study was to determine the number of ATM and the mRNA expression of adipokines [adiponectin $(A D I P O Q)$, leptin $(L E P)$, interleukin 6 (IL6), tumor necrosis factor $(T N F)$, interleukin 10 (IL10)] in different adipose depots from cows with a variable BCS at the end of the dry period. We hypothesized that the number of ATM and the expression of the different adipokines depend on the size of the adipocytes and differ between the different adipose depots.

\section{MATERIALS AND METHODS}

All experimental procedures were approved by the ethical committee of the Faculty of Veterinary Medicine (EC2010/149, Ghent University, Belgium).

\section{Study Design}

Ten clinically healthy, pregnant Holstein Friesian dairy cows (upcoming parity 2 to 5 , age $3.9 \pm 1.4 \mathrm{yr}$, milk yield in the previous lactation $8,750 \pm 1,446 \mathrm{~kg}$; mean $\pm \mathrm{SD}$ ) were selected at the beginning of the dry period based on BCS according to the scale of Edmonson et al. (1989) to ensure an equal spread in BCS from normal conditioned $(2.5-3.5 ; \mathrm{n}=5)$ to over-conditioned $(3.75-5 ; \mathrm{n}=5)$. During the dry period (starting approximately $7 \mathrm{wk}$ before the expected parturition date), animals were weekly monitored by assessment of their BCS and all animals received similar diets to meet but not exceed requirements. A detailed description of the study design and the diets can be found in De Koster et al. (2015).

Cows were euthanized 10 to $13 \mathrm{~d}$ before the expected parturition date (actual days of pregnancy at the moment of euthanasia was $269 \pm 5$ d) at the Department of Morphology (Faculty of Veterinary Medicine, Ghent University, Belgium). Cows were stunned with a captive bolt gun and exsanguinated by transecting the carotid arteries and the jugular veins. Body weight of the animals the day before euthanasia was $717 \pm 77 \mathrm{~kg}$. Immediately after euthanasia, adipose tissue samples were collected from the subcutaneous, omental, mesenteric, perirenal, and intrapelvic adipose depots. The weight of the different adipose depots was determined and is described in De Koster et al. (2015). Subcutaneous adipose tissue samples were taken from the adipose tissue located in the fossa ischiorectalis. Omental adipose tissue samples were taken from the omentum majus at the right side at the level of the pylorus, halfway between the cranial and caudal rim of the omentum. Mesenteric adipose tissue samples were taken $15 \mathrm{~cm}$ proximal from the jejunum. Perirenal adipose tissue samples were taken from the caudal end of the right kidney. Samples for mRNA expression were immediately snap frozen in liquid nitrogen and stored at $-80^{\circ} \mathrm{C}$ until processing. Samples for histology were fixed in $4 \%$ buffered formaldehyde $(\mathrm{pH} \mathrm{7.4)}$ at room temperature for $24 \mathrm{~h}$, subsequently dehydrated in a tissue processor (Microm STP 420D, Prosan, Merelbeke, Belgium) and embedded in paraffin blocks using an embedding station (Microm EC 350-1 and Microm EC 350-2, Prosan). 


\section{Histology}

Two sections ( $8 \mu \mathrm{m}$ thick) of each adipose tissue sample were stained with hematoxylin (Haematoxylin, C.I.75290, Merck KGaA, Darmstadt, Germany) and eosin (Eosin yellow, C.I.45380, VWR International BVBA, Leuven, Belgium). Five images were taken at random of each of the sections at $100 \times$ magnification using an Olympus BX 61 microscope (Olympus, Hamburg, Germany). On each image, the diameter and surface of 10 adipocytes was determined using Cell $\mathrm{F}$ software (Olympus). To avoid using the same adipocyte twice, the 2 sections were made at least $200 \mu \mathrm{m}$ apart.

Immunohistochemistry was done as previously described by Contreras et al. (2015). Sections ( $5 \mu \mathrm{m}$ thick) of formaldehyde fixed subcutaneous, omental, and mesenteric adipose tissue samples were stained using an Autostainer Link 48 (Dako North America Inc., Carpinteria, CA) with a mouse monoclonal antibody to detect CD172a (1:100; DH59B, Washington State University Monoclonal Antibody Center, Pullman, WA). Positive (bovine spleen) and negative (without the primary antibody) controls were included. Sections were counterstained with hematoxylin, and CD172apositive cells were detected using an Olympus BX-40 microscope (Olympus). Five hundred adipocytes were counted and the number of CD172a-positive cells was determined. Additionally, the number of crown-like structures (CLS), being aggregates of CD172a-positive cells, was counted. The proportion of CD172a-positive cells (the number of CD172a-positive cells divided by 500 adipocytes, given as a percentage) was used for further statistical analysis.

Spleen samples were collected postmortem at the Michigan State University Meat Laboratory (East Lansing, MI) from lactating nonpregnant cows, as described in Contreras et al. (2016). Immediately after collection, spleen specimens were placed in a $4 \%$ paraformaldehyde solution and stored at $4^{\circ} \mathrm{C}$ for $24 \mathrm{~h}$, then transferred to $30 \%$ ethanol and stored at $4^{\circ} \mathrm{C}$ for $12 \mathrm{~h}$, and finally embedded in paraffin.

\section{Primer Design, Reference Gene Selection, and PCR}

Primers for $A D I P O Q, L E P, T N F$, and $I L 10$ were designed using Primer3Plus (Untergasser et al., 2007), based on DNA sequences in GenBank (Benson et al., 2013) and avoiding secondary structures predicted with Mfold (Zuker, 2003). Primers for IL6 were used as described by Vailati Riboni et al. (2015). Based upon previous research, 6 candidate reference genes were selected: MARVEL domain containing 1 (MARVELD1), eukaryotic translation initiation factor 3 subunit $\mathrm{K}(E I$ $F 3 K)$, LDL receptor related protein 10 (LRP10), actin $\beta$
$(A C T B)$, tyrosine 3-monooxygenase/tryptophan 5-monooxygenase activation protein zeta ( $Y W H A Z$ ), and hypoxanthine phosphoribosyltransferase 1 (HPRT1; Goossens et al., 2005; Saremi et al., 2012). All primers were ordered from Integrated DNA Technologies (IDT, Leuven, Belgium). Primer and amplicon information can be found in Table 1. Total RNA was isolated using the Aurum Total RNA Fatty and Fibrous Tissue Kit (BioRad Laboratories Inc., Hercules, CA) according to the manufacturer's instructions (http://www.bio -rad.com/webroot/web/pdf/lsr/literature/10001298 .pdf). The samples were homogenized in Purezol using a Tissue Ruptor (Qiagen, Antwerp, Belgium). After RNA isolation, a DNase treatment with $6 \mu \mathrm{L}$ of RQ1 RNase-Free DNase (1 U/ $\mu \mathrm{L}$, Promega, Leiden, the Netherlands) and $3 \mu \mathrm{L}$ of RQ1 DNase 10x Reaction Buffer (Promega) was performed for $15 \mathrm{~min}$ at room temperature. Afterward, RNA was purified by spin-column centrifugation (purification step: 2 times for $7 \mathrm{~min}$ at $16,100 \times g$ at $20^{\circ} \mathrm{C}$, concentration step: 1 time for 3 min at $1,000 \times g$ at $20^{\circ} \mathrm{C}$; Amicon Ultra- 0.5 centrifugal filters, Merck Millipore, Billerica, MA). Quantity and purity of RNA were evaluated with the Nanodrop ND1000 spectrophotometer (Nanodrop Products, Thermo Fisher Scientific, Wilmington, DE). Additionally, RNA integrity was verified by visualization of the ribosomal bands on a $2 \%$ agarose gel. Genomic DNA contamination of the samples was verified by a minus reverse transcription control PCR with LRP10 primers. Only RNA samples with a purity between 1.91 and 2.16 (optical density 260/280 ratio), showing clear ribosomal RNA bands on gel, and free of genomic DNA were reverse transcribed to cDNA with the Improm-II cDNA synthesis kit (Promega, Madison, WI). First, RNA was mixed with $0.5 \mu \mathrm{L}$ of oligo(dT) $(10 \mu M$, IDT) and 0.5 $\mu \mathrm{L}$ of random hexamers $(10 \mu M$, IDT). The mix was heated for $5 \mathrm{~min}$ at $70^{\circ} \mathrm{C}$, followed by cooling on ice for $5 \mathrm{~min}$. Afterward, $4 \mu \mathrm{L}$ of Improm-II $5 \times$ reaction buffer, $2.4 \mu \mathrm{L}$ of $\mathrm{MgCl}_{2}(25 \mathrm{mM}), 1 \mu \mathrm{L}$ of dNTP Mix (10 mM each; Bioline Reagents, London, UK), and $1 \mu \mathrm{L}$ of Improm-II reverse transcriptase were added (Improm-II cDNA synthesis kit, Promega). This mix was incubated for $5 \mathrm{~min}$ at $25^{\circ} \mathrm{C}$ (annealing), $60 \mathrm{~min}$ at $42^{\circ} \mathrm{C}$ (synthesis of cDNA), and 15 min at $72^{\circ} \mathrm{C}$ (reverse transcriptase inactivation).

All PCR reactions were performed in a reaction volume of $10 \mu \mathrm{L}$ on the Eppendorf Mastercycler PCR system (Eppendorf, Rotselaar, Belgium) with $0.5 \mathrm{U}$ of TEMPase Hot Start DNA Polymerase (Ampliqon, Odense, Denmark), $1 \mu \mathrm{L}$ of reaction buffer, $0.2 \mu \mathrm{L}$ dNTP (10 mM each, Bioline Reagents), $1 \mu \mathrm{L}$ of primer $\operatorname{mix}(5 \mu M$ forward and reverse primer, IDT), and $2 \mu \mathrm{L}$ of sample (diluted 1/10). The PCR program consisted of an initial denaturation step $\left(15 \mathrm{~min}\right.$ at $\left.95^{\circ} \mathrm{C}\right)$, fol- 
Table 1. Characteristics of the primers used for reverse-transcription quantitative real-time PCR

\begin{tabular}{|c|c|c|c|c|c|c|}
\hline $\begin{array}{l}\text { Gene } \\
(\mathrm{NCBI} \text { gene ID })^{1}\end{array}$ & Sequence $5^{\prime}-3^{\prime}(\mathrm{F}=$ forward, $\mathrm{R}=$ reverse $)$ & $\begin{array}{l}\text { Product } \\
\text { size } \\
\text { (bp) }\end{array}$ & $\begin{array}{c}\text { Annealing } \\
\text { temperature } \\
\left({ }^{\circ} \mathrm{C}\right)\end{array}$ & $\mathrm{R}^{2}$ & $\begin{array}{l}\text { Efficiency } \\
\quad(\%)\end{array}$ & $\begin{array}{l}\text { GenBank accession } \\
\text { number or reference }\end{array}$ \\
\hline MARVELD1 (616867) & $\begin{array}{l}\text { F: GGCCAGCTGTAAGATCATCACA } \\
\text { R: TCTGATCACAGACAGAGCACCAT }\end{array}$ & 100 & 63.0 & 0.998 & 102.35 & Saremi et al., 2012 \\
\hline EIF3K (515326) & $\begin{array}{l}\text { F: CCAGGCCCACCAAGAAGAA } \\
\text { R: TATACCTTCCAGGAGGTCCATGT }\end{array}$ & 125 & 59.5 & 0.999 & 102.60 & Saremi et al., 2012 \\
\hline LRP10 (515494) & $\begin{array}{l}\text { F: CCAGAGGATGAGGACGATGT } \\
\text { R: ATAGGGTTGCTGTCCCTGTG }\end{array}$ & 139 & 61.0 & 0.999 & 102.30 & Saremi et al., 2012 \\
\hline HPRT1 (281229) & $\begin{array}{l}\text { F: TGCTGAGGATTTGGAGAAGG } \\
\text { R: CAACAGGTCGGCAAAGAACT }\end{array}$ & 154 & 58.0 & 0.999 & 102.25 & Goossens et al., 2005 \\
\hline$Y W H A Z(2870222)$ & $\begin{array}{l}\text { F: GCATCCCACAGACTATTTCC } \\
\text { R: GCAAAGACAATGACAGACCA }\end{array}$ & 120 & 60.0 & 0.999 & 101.90 & Goossens et al., 2005 \\
\hline$A D I P O Q(282865)$ & $\begin{array}{l}\text { F: CCACCTTCACAGGCTTCCTTCT } \\
\text { R: GTTCTTTCACTTTGTGCTGCTTGG }\end{array}$ & 100 & 64.0 & 0.999 & 101.1 & NM_174742.2 \\
\hline TNF (280943) & $\begin{array}{l}\text { F: TGCCTGCTGACGGGCTTTA } \\
\text { R: GCTGATGGTGTGGGTGAGGA }\end{array}$ & 95 & 66.0 & 0.997 & 98.6 & NM_173966.3 \\
\hline IL10 (281246) & $\begin{array}{l}\text { F: AGCCTTGTCGGAAATGATCCAGTTTTA } \\
\text { R: TCTCCACCGCCTTGCTCTTGT }\end{array}$ & 179 & 62.5 & 0.997 & 99.1 & NM_174088.1 \\
\hline
\end{tabular}

${ }^{1} \mathrm{NCBI}=$ National Center for Biotechnology Information.

lowed by 40 cycles of $15 \mathrm{~s}$ at $95^{\circ} \mathrm{C}, 30 \mathrm{~s}$ at the annealing temperature of the primer, and $30 \mathrm{~s}$ at $72^{\circ} \mathrm{C}$, with a final elongation of $2 \mathrm{~min}$ at $72^{\circ} \mathrm{C}$. The PCR products were visualized on a $2 \%$ agarose gel.

The quantitative PCR reactions were performed using KAPA SYBR FAST qPCR kit master mix (Kapa Biosystems, Wilmington, MA) in a reaction volume of $10 \mu \mathrm{L}$ containing $5 \mu \mathrm{L}$ of KAPA SYBR FAST, $1 \mu \mathrm{L}$ of primers ( $5 \mu M$ forward and reverse), and $2 \mu \mathrm{L}$ of cDNA sample (10-fold diluted). The quantitative PCR was conducted on a CFX96 Touch Real-Time PCR Detection System (BioRad Laboratories Inc.) and started at $95^{\circ} \mathrm{C}$ for $4 \mathrm{~min}$, followed by 40 cycles of $20 \mathrm{~s}$ at $95^{\circ} \mathrm{C}$, and $40 \mathrm{~s}$ at the annealing temperature of the primer with detection of fluorescence. A melting curve was generated by heating the samples from 70 to $95^{\circ} \mathrm{C}$ in steps of $0.5^{\circ} \mathrm{C}$ for $5 \mathrm{~s}$ with fluorescence detection. In each run, a serial dilution (6-points, 4-fold dilution) of a cDNA sample and a negative control sample were included to determine the efficiency, the correlation coefficient and potential contamination. All reactions were performed in duplicate. The stability of the reference genes was checked using GeNorm (Vandesompele et al., 2002). The quantification cycle values of the target genes were converted to raw data based on the efficiency of the quantitative PCR, after which they were normalized with the geometric mean of the 3 most stable reference genes (MARVELD1, EIF3K, and LRP10) as described by Erkens et al. (2006). Nondetects $(A D I P O Q, \mathrm{n}=2$;
$L E P, \mathrm{n}=2 ; I L 6, \mathrm{n}=5 ; T N F, \mathrm{n}=7 ;$ and $I L 10, \mathrm{n}=2)$ were treated as missing data in the statistical analyses. Information about reverse transcription quantitative real-time PCR performance can be found in Table 1 and Supplemental Table S1 (https://doi.org/10.3168/ jds.2017-13777).

\section{Statistical Analyses}

Statistical analyses were performed using SAS version 9.4 (SAS Institute Inc., Cary, NC). Descriptive statistics (PROC MEANS) are expressed as mean \pm standard error of the means unless otherwise indicated. Normality of the variables (PROC UNIVARIATE) was checked using the Kolmogorov-Smirnov test.

For the comparison of the size of the adipocytes between depots, diameter and area of the adipocytes were fitted as dependent variables in a linear mixed model and depot was included as an independent variable. Cow was included as a random factor. Because diameter and area were log-normally distributed, the model was fitted using a generalized linear mixed model (PROC GLIMMIX) using the DIST = LOGNORMAL statement. Pairwise comparisons between depots were checked using the LSMEANS statement (Tukey posthoc test).

To determine the factors affecting the proportion of ATM or the mRNA expression of the different genes, a linear mixed model was built with the proportion 
of ATM and the expression of the individual genes as dependent variable, whereas depot, average adipocyte area per depot, and the interaction between depot and adipocyte area were included as independent variables; cow was included as a random factor. Interaction terms were left out of the model if not significant $(P>0.10)$. Because the proportion of ATM and the expression of the genes were log-normally distributed, the model was fitted using a generalized linear mixed model (PROC GLIMMIX) using the DIST = LOGNORMAL statement. Pairwise comparisons between depots were checked using the LSMEANS statement (Tukey posthoc test).

To determine the relationship between the expression of the different adipokines and the proportion of ATM, a linear mixed model (PROC MIXED) was built with the proportion of ATM and the mRNA expression of each gene (both were log transformed to yield normal distribution) as dependent variables and the mRNA expression of the other genes (after log transformation to yield normal distribution) as independent variables. Cow was included as a random factor. Regression coefficients of the different models are presented to demonstrate the relationship between the proportion of ATM and the expression of the individual adipokines. We tested the effect of parity in the different models and parity was not withheld in the final model because it did not significantly affect any of the variables in the study. Pearson correlation coefficients were calculated between the average area of the adipocytes per depot and the BCS (average BCS during the dry period). Significance and tendency were declared at $P<0.05$ and $0.05<P<0.10$, respectively.

\section{RESULTS}

Mesenteric adipocytes were significantly smaller compared with the other depots (Table 2). Pearson correlation coefficients between the average BCS of the cows during the dry period and the adipocyte size were strong and significantly positive in all the depots: subcutaneous $(\mathrm{r}=0.97 ; P<0.05)$, mesenteric $(\mathrm{r}=0.80 ; P$ $<0.05)$, omental $(\mathrm{r}=0.85 ; P<0.05)$, intrapelvic $(\mathrm{r}=$ $0.92 ; P<0.05)$, and perirenal adipose tissue $(\mathrm{r}=0.90$; $P<0.05)$.

Expression of the different genes in the different adipose tissue depots is represented in Table 3 and Figure 1, whereas the relationship between the size of the adipocytes and the expression of the different genes is represented in Table 4 and Figure 2. Expression of $A D I P O Q$ was not influenced by adipocyte size $(P>$ $0.05)$, but was significantly influenced by adipose depot $(P<0.05)$, with lower expression in the subcutaneous depot when compared with the intrapelvic and perirenal depots. Expression of $L E P$ was significantly different between the adipose depots $(P<0.05)$, with lower expression in the subcutaneous and omental depots compared with the intrapelvic depot. We noted a trend $(0.05<P<0.10)$ for lower LEP expression in the subcutaneous depot compared with the mesenteric and perirenal depots. The effect of adipocyte size on the expression of $L E P$ was dependent on the adipose depot (interaction effect). The expression of $L E P$ was positively associated with adipocyte size, and this was more pronounced in the mesenteric adipose depot. Expression of $I L 6$ and $T N F$ was greater in larger adipocytes $(0.05<P<0.10)$. Expression of IL6 was influenced by the adipose $\operatorname{depot}(P<0.05)$, with lower expression in the subcutaneous depot when compared with the other depots. Expression of TNF was influenced by the adipose depot $(P<0.05)$, with higher expression in the subcutaneous and omental depots when compared with the intrapelvic depot. Expression of $I L 10$ was influenced by the adipose depot $(P=0.05)$, with higher expression of IL10 in the omental depot compared with the subcutaneous adipose depot. The relationship between the expression of different genes is represented by the coefficients of the linear mixed model (Table 4) and the scatterplot (Figure 3). Within the different adipose depots, we observed a positive

Table 2. Adipocyte size and macrophage count (mean \pm SEM) by adipose depot $(\mathrm{n}=10)$

\begin{tabular}{|c|c|c|c|c|c|}
\hline \multirow[b]{2}{*}{ Parameter } & \multicolumn{5}{|c|}{ Adipose depot } \\
\hline & Subcutaneous & Mesenteric & Omental & Intrapelvic & Perirenal \\
\hline Adipocyte area $\left(\mu \mathrm{m}^{2}\right)$ & $10,475 \pm 1,019^{\mathrm{a}}$ & $8,500 \pm 780^{\mathrm{b}}$ & $10,383 \pm 1,227^{\mathrm{a}}$ & $11,466 \pm 1,039^{\mathrm{a}}$ & $11,087 \pm 1,632^{\mathrm{a}}$ \\
\hline Adipocyte diameter $(\mu \mathrm{m})$ & $118.65 \pm 5.23^{\mathrm{a}}$ & $107.93 \pm 3.39^{\mathrm{b}}$ & $117.31 \pm 5.45^{\mathrm{a}}$ & $123.99 \pm 4.70^{\mathrm{a}}$ & $120.65 \pm 7.62^{\mathrm{a}}$ \\
\hline $\operatorname{ATM}^{1}(\%)$ & $1.92 \pm 0.55^{\mathrm{a}}$ & $1.10 \pm 0.33^{\mathrm{a}}$ & $8.28 \pm 2.24^{\mathrm{b}}$ & $\underline{-}^{2}$ & - \\
\hline Number of crown-like structures ${ }^{3}$ & 0 & $0.10 \pm 0.01$ & $1.50 \pm 0.60$ & - & - \\
\hline
\end{tabular}

\footnotetext{
${ }^{\mathrm{a}, \mathrm{b}}$ Means within a row with different superscript letters differ significantly $(P<0.05)$.

${ }^{1}$ Adipose tissue macrophages (ATM) represented as the proportion of CD172a-positive cells per 100 adipocytes.

${ }^{2}$ The number of CD172a-positive cells was not determined in the intrapelvic and perirenal adipose depot.

${ }^{3}$ Number of aggregates of CD172a-positive cells.
} 
Table 3. Relative mRNA expression (mean $\pm \mathrm{SEM}$ ) of $A D I P O Q, L E P, I L 6, T N F$, and $I L 10$ in different adipose depots

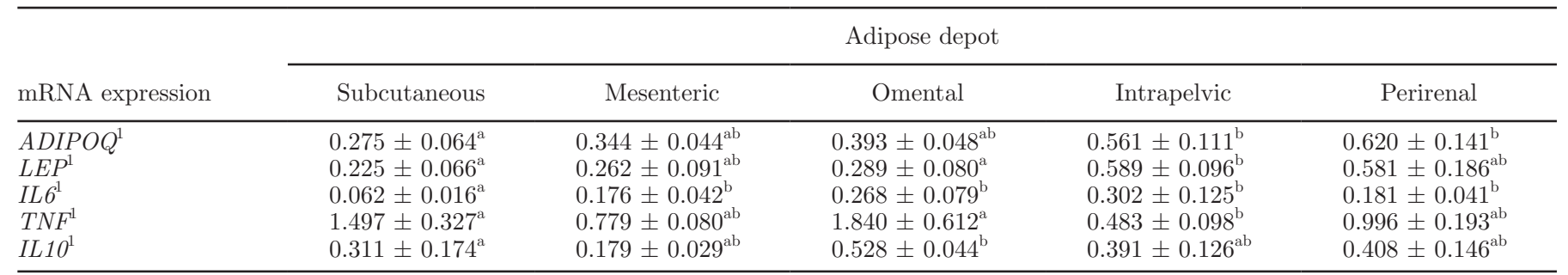

${ }_{\mathrm{a}, \mathrm{b}}$ Means within a row with different superscript letters differ significantly $(P<0.05)$.

${ }^{1}$ mRNA expression of the genes is presented as relative mRNA abundance after normalization with the reference genes $(M A R V E L D 1$, EIF3K, and $L R P 10$ ). There were 2 nondetects for $A D I P O Q, 2$ for $L E P T, 5$ for IL6, 7 for TNF, and 2 for IL10.

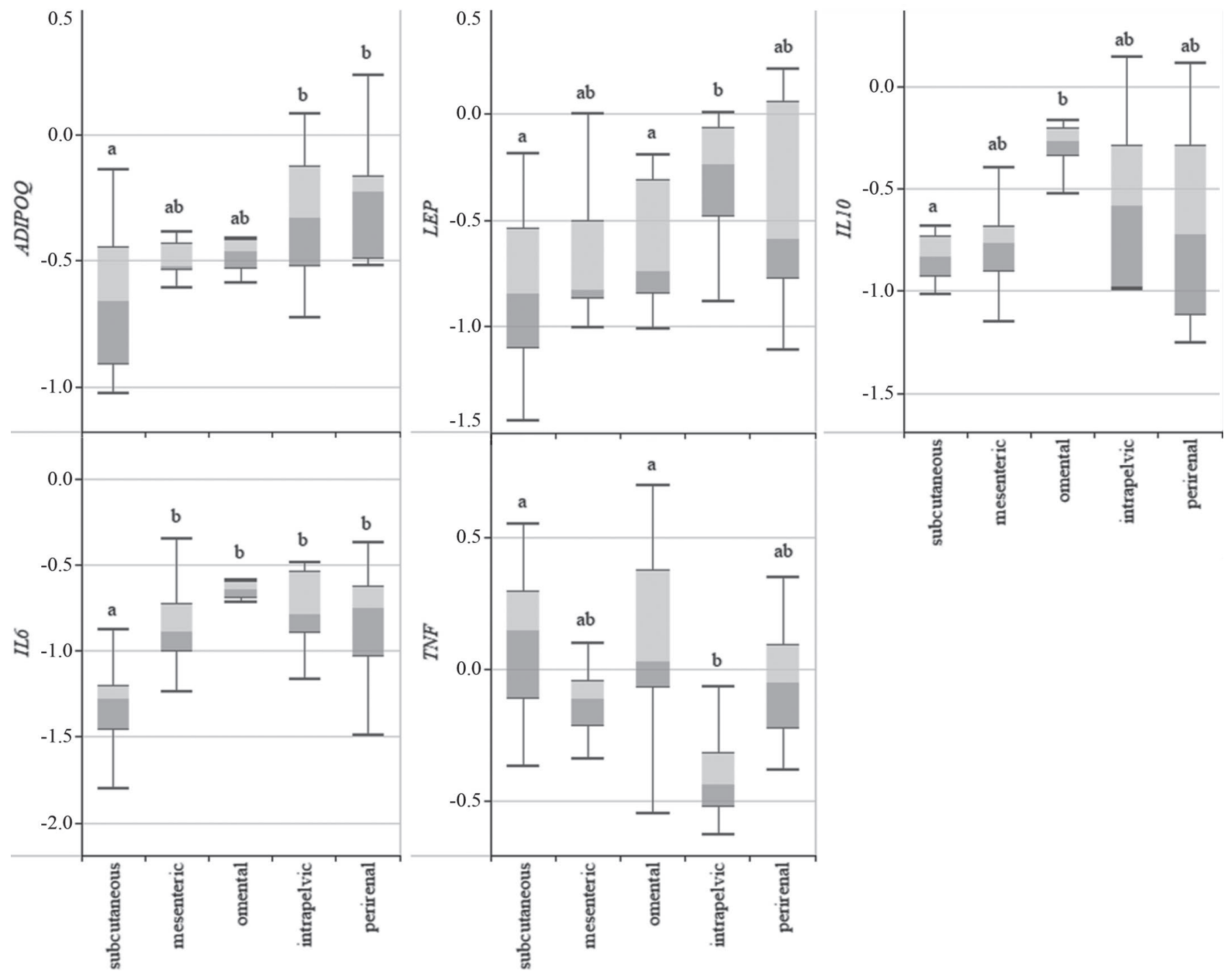

Figure 1. The mRNA expression of the different adipokines (ADIPOQ, LEP, IL6, TNF, and IL10) in the subcutaneous, omental, mesenteric, intrapelvic, and perirenal adipose depots. The mRNA expression is presented as relative mRNA abundance after normalization with the reference genes (MARVELD1, EIF3K, and LRP10) and log transformation. Depots with different letters $(\mathrm{a}, \mathrm{b})$ differ significantly $(P<0.05)$. There were 2 nondetects for $A D I P O Q, 2$ for $L E P T, 5$ for $I L 6,7$ for $T N F$, and 2 for $I L 10$. Box $=$ middle $50 \%$ of the data; upper whisker: maximum; lower whisker: minimum; shading: indicates median. 


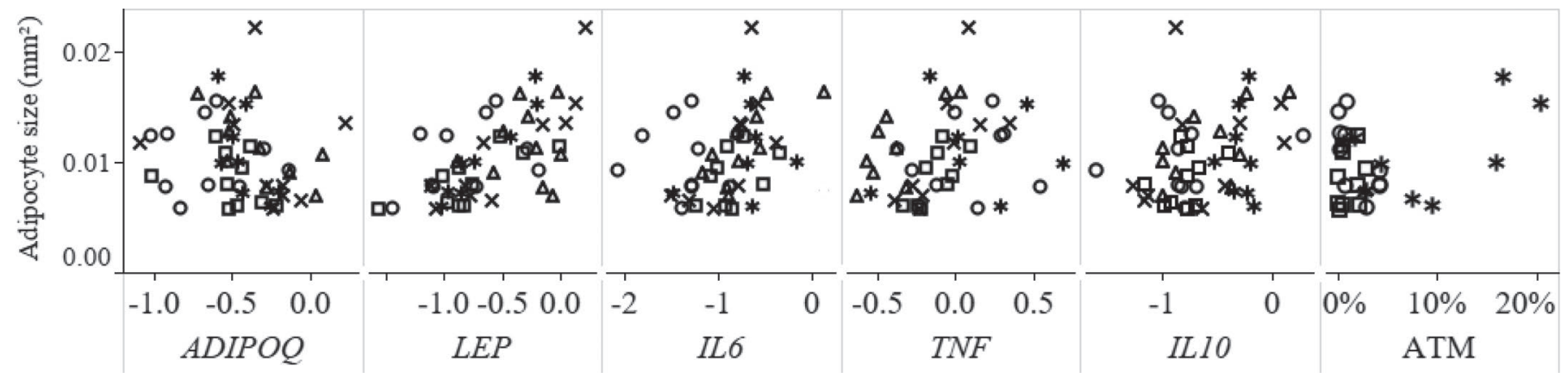

Figure 2. Relationship between the mRNA expression of the different adipokines (ADIPOQ, LEP, IL6, TNF, and IL10), the proportion of adipose tissue macrophages (ATM; represented as the proportion of CD172a-positive cells per 100 adipocytes), and adipocyte size (mm ${ }^{2}$ ) throughout the different adipose depots (5 adipose depots in 10 cows). The mRNA expression is presented as relative mRNA abundance after normalization with the reference genes $(M A R V E L D 1, E I F 3 K$, and LRP10) and log transformation. Subcutaneous adipose tissue = ; mesenteric adipose tissue $=\square$; omental adipose tissue $=*$; intrapelvic adipose tissue $=\Delta$; perirenal adipose tissue $=\times$.

relationship between $A D I P O Q$ and $L E P, I L 6$ and $L E P$, $I L 10$ and TNF, and IL6 and IL10. Furthermore, we found a negative relationship between $A D I P O Q$ and $T N F$ as well as ADIPOQ and IL10.

In all the adipose tissue samples evaluated for ATM infiltration with immunohistochemistry, CD172apositive cells (ATM) were detected. We observed significantly more ATM in the omental adipose depot compared with the subcutaneous and the mesenteric adipose depots (Table 2, Figure 4). Adipose tissue macrophages could be detected in CLS or as single ATM (Figure 5). Crown-like structures were not detected in the subcutaneous depot and very rarely detected in the mesenteric depot (only in $1 \mathrm{cow}$ ), whereas multiple CLS could be detected in the omental adipose depot of multiple cows. The proportion of ATM was influenced by the size of adipocytes. In the subcutaneous adipose depot we found a negative relationship between the proportion of ATM and the size of the adipocytes, whereas in the omental and mesenteric adipose depot we noted a positive relationship. The proportion of ATM was not related to the gene expression of any of the genes in this study (Table 4, Figure 3).

\section{DISCUSSION}

Over-conditioned cows are prone to the development of a variety of metabolic and infectious disorders, which is known as fat cow syndrome (Morrow, 1976; Roche et al., 2009). The cows in the present study were fed ac-

Table 4. Coefficients of the univariate regression models describing the relationship between the relative expression of the different genes, the area of the adipocytes, and the number of adipose tissue macrophages

\begin{tabular}{lcccccc}
\hline & \multicolumn{5}{c}{ Dependent variable } \\
\cline { 2 - 6 } Independent variable & ADIPOQ & LEP & IL6 & TNF & IL10 & ATM $^{2}$ \\
\hline Adipocyte area $^{3}\left(\mathrm{~mm}^{2}\right)$ & -15.30 & $113.47 \dagger$ & $76.57 \dagger$ & $50.29 \dagger$ & 58.17 & $-251.55^{*}$ \\
ADIPOQ $^{4}$ & & $0.26^{*}$ & -0.03 & $-0.34^{*}$ & $-0.17 \dagger$ & 0.50 \\
$L E P^{4}$ & $0.58^{*}$ & & $0.29 \dagger$ & -0.12 & 0.13 & 0.19 \\
$I L 6^{4}$ & -0.07 & $0.26 \dagger$ & & 0.23 & $0.45^{*}$ & 0.36 \\
$T N F^{4}$ & $-0.41^{*}$ & -0.06 & 0.12 & & $0.26^{*}$ & 0.46 \\
$I L 10^{4}$ & $-0.33 \dagger$ & 0.11 & $0.39^{*}$ & $0.43^{*}$ & & 0.38 \\
\hline
\end{tabular}

${ }^{1}$ Effect of adipocyte size on leptin expression was dependent on the depot (interaction effect, $P<0.05$ ) only in the mesenteric adipose depot; adipocyte size was positively associated with the expression of leptin (regression coefficient $=340.15, P<0.05)$.

${ }^{2}$ Adipose tissue macrophages (ATM) determined as the proportion of CD172a-positive cells per 100 adipocytes. Effect of adipocyte size on the proportion of ATM was dependent on the depot (interaction effect, $P=0.05$ ), the proportion of ATM was negatively related to adipocyte size in the subcutaneous adipose depot (regression coefficient $=-251.55, P<0.05$ ), whereas the proportion of ATM was positively related to adipocyte size in the mesenteric and omental adipose depot (regression coefficient $=67.23,0.05<P<0.10$, regression coefficient $=74.36, P<0.05$, respectively).

${ }^{3}$ Regression coefficients of the generalized linear mixed model.

${ }^{4}$ Regression coefficients of the linear mixed model.

$* P<0.05 ; \dagger 0.05<P<0.1$. 


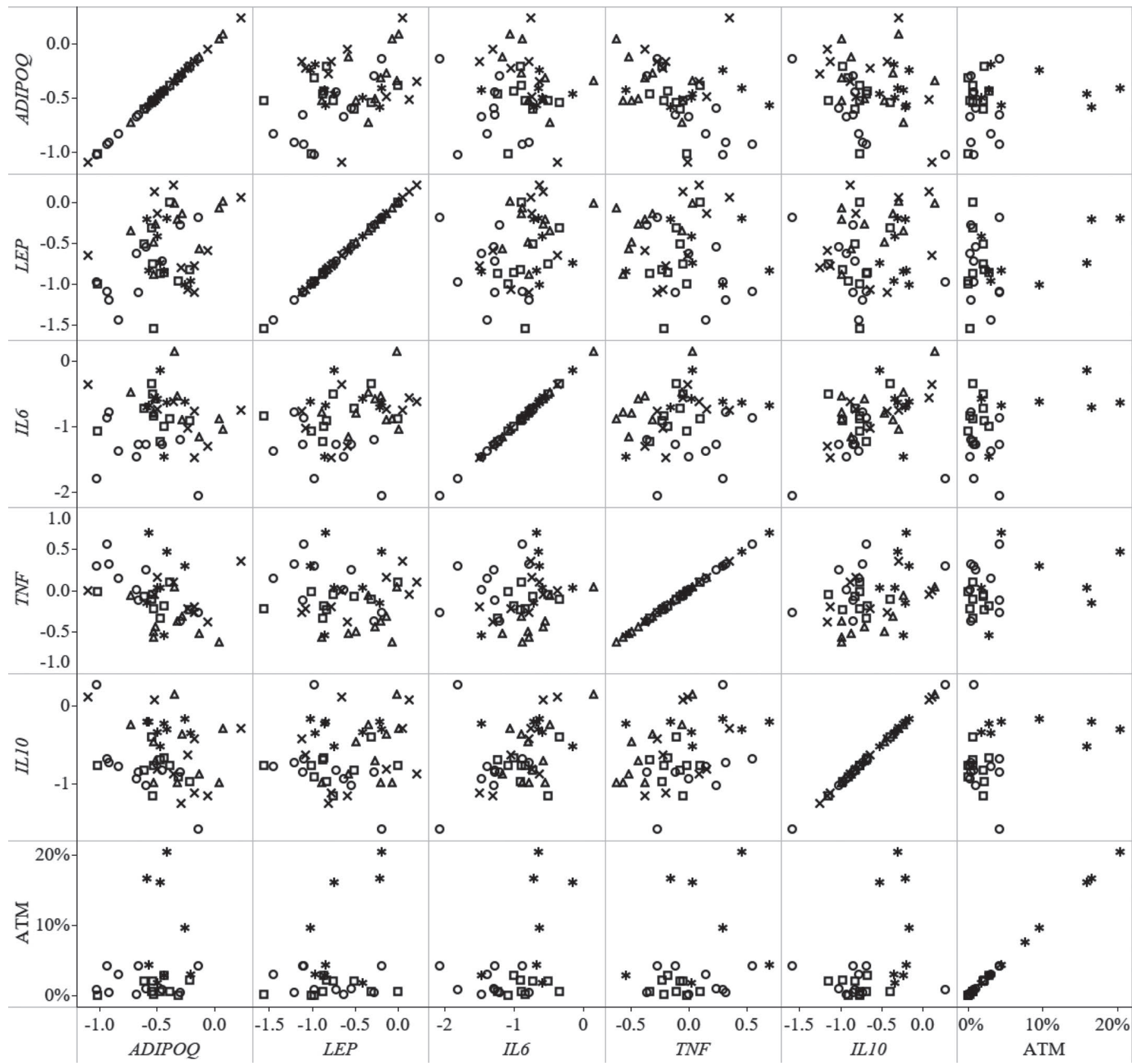

Figure 3. Relationship between the mRNA expression of the different adipokines (ADIPOQ, LEP, IL6, TNF, and IL10) and the proportion of adipose tissue macrophages (ATM; represented as the proportion of CD172a-positive cells per 100 adipocytes) throughout the different adipose depots ( 5 adipose depots in 10 cows). The mRNA expression is presented as relative mRNA abundance after normalization with the reference genes (MARVELD1, EIF3K, and LRP10) and log transformation. Subcutaneous adipose tissue $=0$; mesenteric adipose tissue $=\square$; omental adipose tissue $=*$; intrapelvic adipose tissue $=\Delta$; perirenal adipose tissue $=\times$.

cording to their requirements and did not gain nor lose BCS during the dry period (De Koster et al., 2015). The excessive BCS in the over-conditioned cows was most probably due to a prolonged positive energy balance at the end of the previous lactation. Different papers demonstrated a dysregulated inflammatory reaction in over-conditioned cows. Cows with high BCS had greater concentrations of markers for oxidative stress, decreased functional properties of circulating mononuclear cells (lower IFN- $\gamma$ and IgM secretion) and greater plasma levels of tumor necrosis factor (TNF; Bernabucci et al., 2005; Lacetera et al., 2005; O'Boyle et al., 2006). To the 
contrary, in the study of Akbar et al. (2015), high-BCS cows (5.0 on a 10-point scale), when compared with low- and medium-BCS cows (3.0 and 4.0 on a 10-point scale, respectively), demonstrated a lower inflammatory response after calving, as measured by systemic and hepatic indicators of inflammation. Overfeeding nonpregnant, nonlactating cows for a period of $8 \mathrm{wk}$ did not induce an inflammatory response within the adipose tissue as measured by mRNA expression ( $\mathrm{Ji}$ et al., 2014b). Discrepancies between different studies may be explained by the fact that periparturient inflammation and immune function are influenced by different factors such as energy balance, diet, metabolites such as free fatty acids, individual variation in lipolytic responses, subclinical disorders, BCS, and many other factors (Esposito et al., 2014; Bradford et al., 2015; Sordillo, 2016).

The aim of the present study was to describe the potential role of the adipose tissue in creating a proinflammatory state in over-conditioned cows. More specifically, we aimed to determine the association between the size of the adipocytes, the location of the adipose depot, the mRNA expression for $A D I P O Q, L E P, I L 6$, $T N F$, and IL10 and the proportion of ATM in adipose tissue samples taken from dairy cows with a variable BCS at the end of pregnancy.

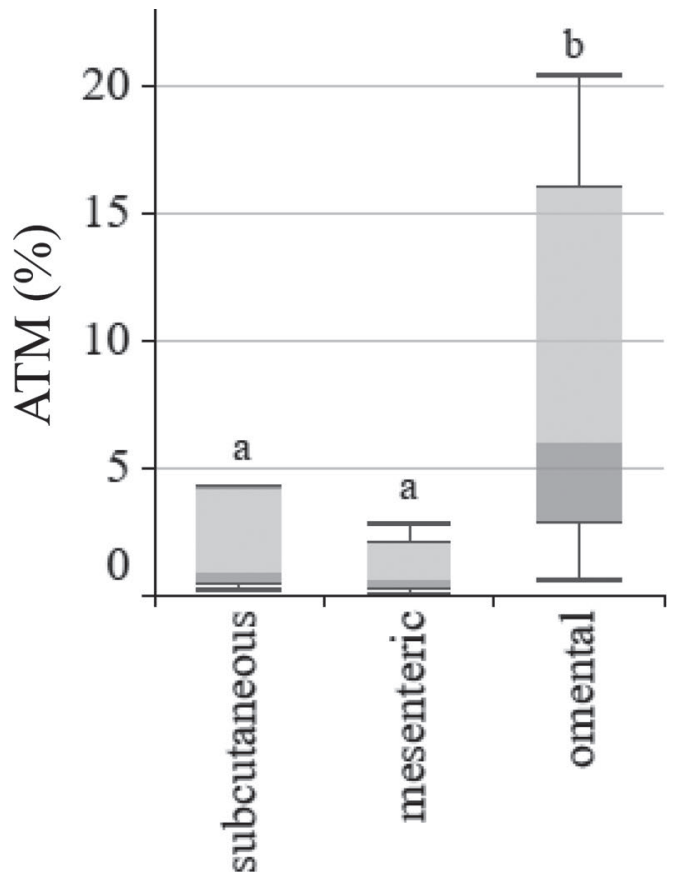

\section{Adipocyte Size}

Over-conditioned cows have larger adipocytes, as demonstrated by the strong correlation between BCS and adipocyte size in every adipose depot examined in the present study. The latter supports the observation that accumulation of lipids in adult cows is mainly mediated via hypertrophy of the adipocytes instead of via hyperplasia (Hood and Allen, 1973; Smith and McNamara, 1990; McNamara, 1991). Differences in adipocyte size between depots are related to depot-specific differences in adipose tissue metabolism, namely accumulation or release of lipids (Akter et al., 2011). In the present study, the difference in adipocyte size between depots is probably a reflection of a different lipogenic activity in different adipose depots at the end of the previous lactation due to the fact that cows were not yet metabolically triggered to release large amounts of lipids at the moment of euthanasia. Khan et al. (2013) suggested that lipogenesis is mainly genetically controlled (by transcription of key lipogenic proteins), wheras lipolysis is regulated by posttranslational modifications. As a consequence, expression of lipogenic genes reflects the lipogenic potential of an adipose $\operatorname{depot}$ (Ji et al., 2014b). Ji et al. (2014a) demonstrated different expression of lipogenic genes

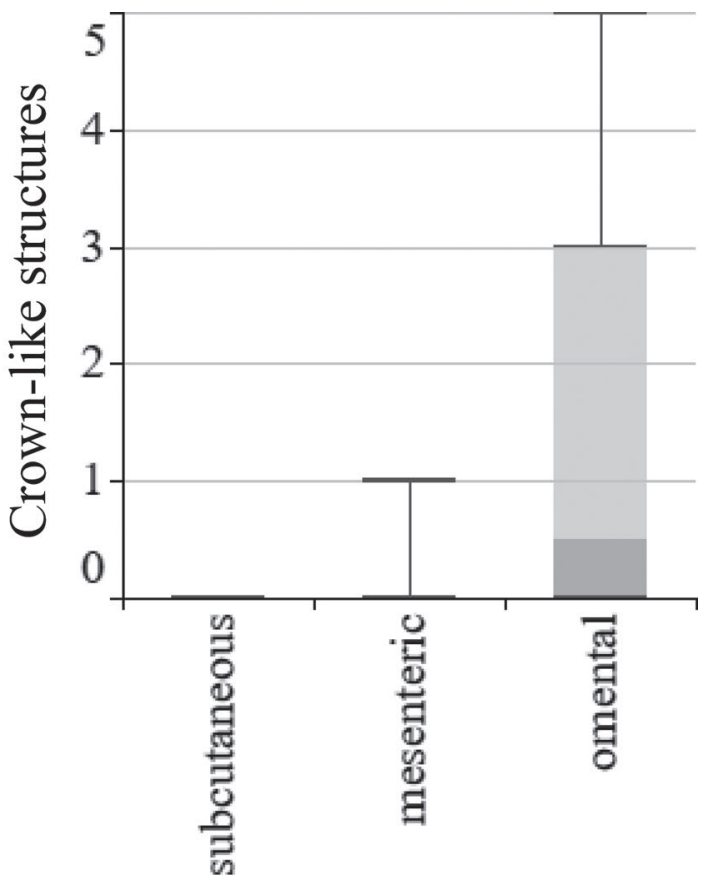

Figure 4. Proportion of adipose tissue macrophages (ATM; presented as the proportion of CD172a-positive cells per 100 adipocytes) and number of crown-like structures (number of aggregates of CD172a-positive cells) in the subcutaneous, mesenteric, and omental adipose depots (n $=10)$. Depots with different letters $(\mathrm{a}, \mathrm{b})$ differ significantly $(P<0.05)$. Box: middle $50 \%$ of the data; upper whisker: maximum; lower whisker: minimum; shading: indicates median. 
A

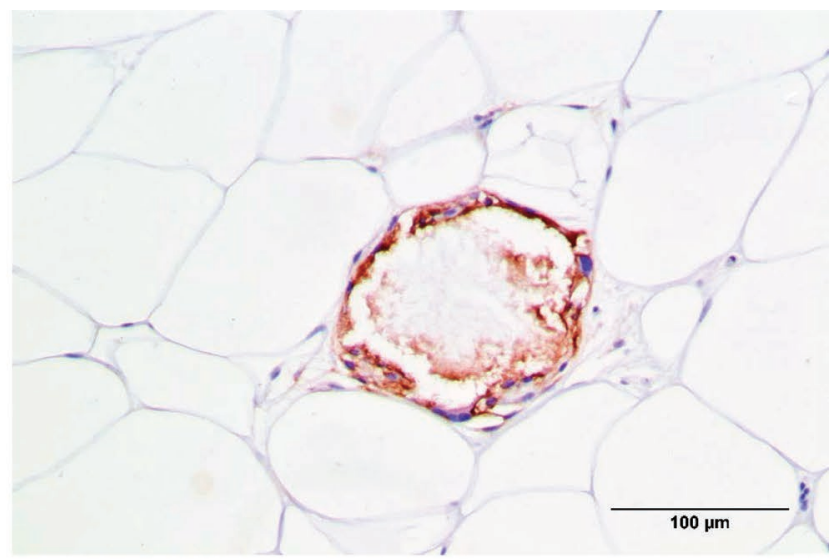

B

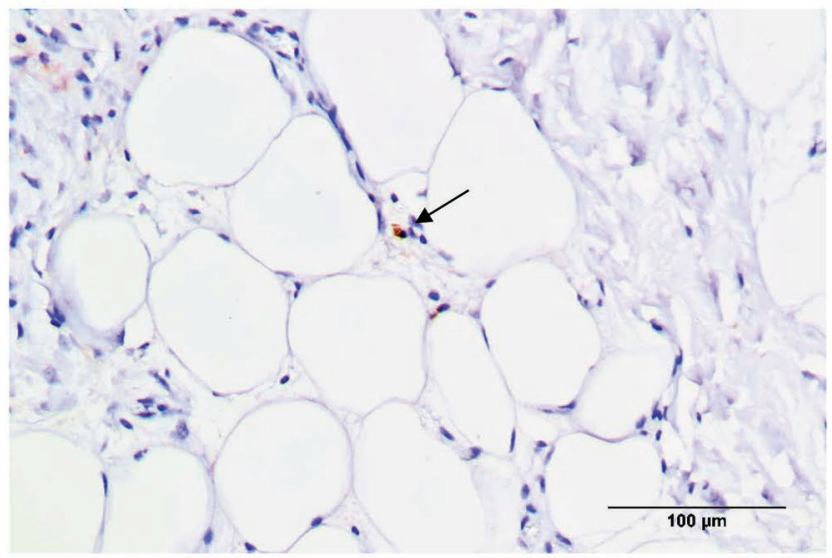

$\mathrm{C}$

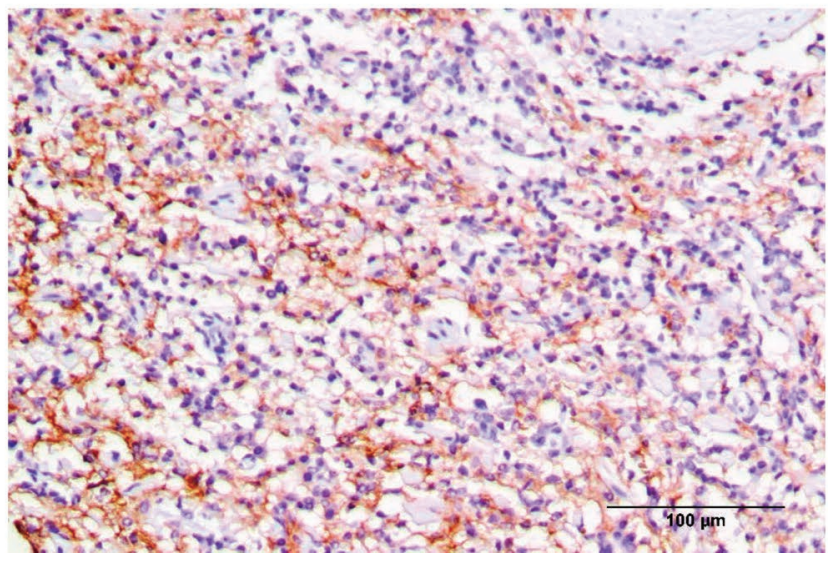

Figure 5. Images of tissue sections after immunohistochemical staining using CD172a antibodies to detect adipose tissue macrophages (ATM). Adipose tissue macrophages were localized in crownlike structures (A) or as sole ATM throughout the tissue (B). Bovine spleen was used as positive control $(\mathrm{C})$. Color version available online.

between the subcutaneous, omental, and mesenteric adipose depots in nonpregnant, nonlactating cows. The results of Ji et al. (2014a) are consistent with a greater lipogenic potential in subcutaneous compared with mesenteric adipose tissue; the latter might explain the smaller adipocyte size in the mesenteric adipose tissue observed in the present study.

\section{Influence of Adipocyte Size and Adipose Depot on ADIPOQ and LEP Expression}

Adipocytes are the main source of circulating adiponectin and leptin (Chilliard et al., 2005; Singh et al., 2014). In humans and rodents, both adipokines play an important role in the regulation of energy homeostasis and immune function (Ingvartsen and Boisclair, 2001; Kadowaki and Yamauchi, 2005; Carbone et al., 2012). In dairy cows, expression of $L E P$ in the adipose tissue is strongly related to the serum levels of leptin and is determined by chronic and acute regulatory mechanisms (Chilliard et al., 2005; Drackley et al., 2006). Long-term effects are regulated by body fatness whereas shortterm effects are regulated by feed intake and energy balance. During negative energy balance and feed deprivation, leptin concentrations decrease (Chilliard et al., 2005). Cows in the present study were in positive energy balance and not deprived of feed; thus, leptin levels were mainly determined by body fatness. This might explain the positive association between leptin and the adipocyte size, as described previously (Chilliard et al., 2005).

Expression of $L E P$ was furthermore greater in the intrapelvic adipose depot. Expression of $A D I P O Q$ was greater in the retroperitoneal adipose depots (intrapelvic and perirenal adipose tissues) when compared with the subcutaneous adipose depot. Similarly, in the study of Saremi et al. (2014), LEP and ADIPOQ expression were numerically greater in the retroperitoneal adipose depot. It should be noted that the expression of $A D I P O Q$ is not correlated with serum concentrations of adiponectin. Adiponectin production is mainly controlled by posttranscriptional factors (Lemor et al., 2009; Singh et al., 2014). Therefore, the lack of association between adipocyte size and $A D I P O Q$ expression in the present study does not exclude a potential association between adiponectin concentration and fatness of the animals. Indeed, a negative correlation between serum adiponectin concentration and BCS has been demonstrated (Singh et al., 2014; De Koster et al., 2017). Besides its well-described role in the regulation of feed intake, leptin exerts proinflammatory effects by activating the inflammatory cascade in immune cells in humans and rodents (Ingvartsen and Boisclair, 2001; Paz-Filho et al., 2012). To the contrary, adiponectin exerts anti-inflammatory effects (Yamauchi and Kadowaki, 2008), and these anti-inflammatory effects have been confirmed in bovine monocytes after an in vitro LPS challenge (Kabara et al., 2014). In humans 
and rodents, leptin and adiponectin exert both insulin sensitizing effects mainly by activating adenosine monophosphate-activated protein kinase (AMPK), which increases fatty acid oxidation in skeletal muscle. This will lead to decreased triglyceride accumulation, which is associated with improved insulin sensitivity of skeletal muscle (Kahn and Flier, 2000; Kadowaki and Yamauchi, 2005). Recent studies indicate similar functionality of adiponectin in ruminants. In dairy cows, an improved insulin response of the fatty acid and glucose metabolism was associated with higher circulating adiponectin levels (De Koster et al., 2017). In vitro AMPK activation was increased and triglyceride content decreased in bovine hepatocytes treated with adiponectin (Chen et al., 2013). At the level of the adipocyte, the effects of leptin and adiponectin are counter-regulatory. Adiponectin stimulates lipogenesis whereas leptin inhibits lipogenesis and stimulates lipolysis (Stern et al., 2016). Most of these studies are performed in humans and rodents, whereas in ruminants more research is warranted to elucidate how leptin and adiponectin affect the metabolism of periparturient cows.

\section{Influence of Adipocyte Size and Adipose Depot on ATM}

Besides adipocytes, the white adipose tissue contains preadipocytes, fibroblasts, endothelial cells, T lymphocytes, and macrophages (Heilbronn and Campbell, 2008; Contreras et al., 2017). Obesity in humans is associated with an increased infiltration of ATM and an increased production of proinflammatory cytokines (Heilbronn and Campbell, 2008). In primiparous cows with a moderate BCS, Akter et al. (2012) did not detect a meaningful infiltration of macrophages in adipose tissue sampled during the first months of lactation. Presence of ATM was greater in biopsies taken from over-conditioned heifers and steers (Akter et al., 2012). Although the number of ATM was limited, a positive correlation between the number of macrophages and the size of the adipocytes was demonstrated (Akter et al., 2012). In cows overfed during the close-up period, microRNA markers associated with ATM infiltration were upregulated in subcutaneous adipose tissue (Vailati-Riboni et al., 2017). In the present study, the proportion of ATM was higher in the omental adipose depot and positively associated with adipocyte size in the omental and mesenteric adipose depots. Furthermore, CLS were obviously present in the omental adipose depot. Similarly, Akter et al. (2012) detected lower amounts of ATM in subcutaneous versus visceral adipose tissue and Contreras et al. $(2015 ; 2016)$ found a marked infiltration of ATM in subcutaneous and omental adipose tissue of dairy cows with a left displacement of the abomasum (DA) or after feed restriction. The omental adipose tissue of the DA cows was especially infiltrated with ATM, which were localized in aggregates similar to the CLS observed in human obesity (Cinti et al., 2005; Contreras et al., 2015). The role of these ATM in the development of a proinflammatory state depends on the polarization of the ATM in the adipose tissue (Contreras et al., 2015). Classically activated ATM (M1) are induced by inflammatory stimuli (TNF, LPS) and upon activation, these macrophages produce large amounts of proinflammatory cytokines (TNF, IL-6). Alternatively activated ATM are induced by exposure to IL- 4 and IL-13 and produce anti-inflammatory cytokines (IL-10). Classically activated ATM are responsible for inflammation and have high microbicidal activity, whereas alternatively activated ATM are responsible for the resolution of inflammation and tissue repair (Lumeng et al., 2007; Surmi and Hasty, 2008; Olefsky and Glass, 2010). In the present study, expression of IL6,TNF, and IL10 in the adipose depots were not related to the proportion of ATM. Despite the fact that in humans adipose expression of IL6 (Sindhu et al., 2015), TNF (Hotamisligil et al., 1995) and IL10 (Juge-Aubry et al., 2005) has been linked with protein expression, we cannot exclude possible posttranslational regulation of these proteins in the present study. An additional factor that might confound the results of the present study is the fact that mRNA expression was determined at the level of the adipose tissue. This comprises the mRNA expression of all the cells that reside within the adipose tissue, including preadipocytes, fibroblasts, endothelial cells, mast cells, dendritic cells, neutrophils, eosinophils, basophils, lymphocytes, and macrophages (Heilbronn and Campbell, 2008; Contreras et al., 2018). Based on the results of the present study, it is not possible to identify the cellular source of the different adipokines. As such, more research is needed to identify the cellular source of the adipokines and the polarization and function of ATM in the different adipose depots of dairy cows.

\section{Influence of Adipocyte Size and Adipose Depot on IL6, TNF, and IL10 Expression}

Based on the positive association between adipocyte size and the expression of IL 6 and TNF, we hypothesized that, in over-conditioned cows, IL-6 and TNF originating from adipose depots with large adipocytes could support the development of a low-grade inflammatory state by enhancing the production of proinflammatory molecules, which may lead to a dysregulation of inflammatory processes (Loor et al., 2006, 2007). This hypothesis could not be confirmed in the study of Akbar et al. (2015); however, the BCS of the over-conditioned 
animals in that study (5.0 on a 10-point scale) was not as extreme as the BCS of the over-conditioned cows in the present study (5.0 on a 5 -point scale).

Tumor necrosis factor links inflammatory processes with negative health consequences. Expression of TNF is increased in adipose tissue of DA cows and fatty liver cows had greater serum TNF (Ohtsuka et al., 2001; Contreras et al., 2015). Daily subcutaneous injections of TNF induced hepatic accumulation of triglycerides in lactating cows (Bradford et al., 2009). However, when administered as a continuous low dose infusion in the adipose tissue, no obvious infiltration of fat in the liver was noted and an anti-inflammatory reaction (increased IL10 production) was observed in the liver and the adipose tissue (Martel et al., 2014). Similarly, the expression of $I L 10$ in the adipose samples of the cows in the present study was positively associated with the expression of TNF and IL6. Possibly, IL-10 compensates for the locally increased production of proinflammatory adipokines. As such, it can be questioned if the locally increased production of proinflammatory cytokines in adipose depots has a negative influence on metabolic and inflammatory pathways of over-conditioned dairy cows at the end of pregnancy. More research is needed to determine the potential effect of ATM, the local production of pro- and anti-inflammatory molecules in adipose tissue of dairy cows, the inflammatory profile of these cows, and potential health consequences.

\section{CONCLUSIONS}

In dairy cows, adipose tissue is a potential source of inflammatory mediators. Expression of inflammatory genes (TNF, IL6, and $L E P T)$ is upregulated in adipose depots with enlarged adipocytes in dairy cows at the end of pregnancy. Increased presence of ATM in the omental adipose depot in cases of increased adipocyte size indicates a potential influence of ATM in metabolic and inflammatory properties of this depot. Furthermore, different adipose depots are characterized by a difference in the mRNA abundance of adipokines, which indicates that inflammatory properties may be clearly different between adipose depots within the same animal.

\section{ACKNOWLEDGMENTS}

This research was supported by FWO Vlaanderen (Brussels, Belgium), grant number 3F008513, the Special Research Fund of Ghent University, grant number 01D28410 and USDA-NIFA grant 2015-67015-23207 (Washington, DC). The authors thank Carolien Rogiers (Ghent University, Ghent, Belgium) and Connor
Lewicki (Michigan State University, East Lansing) for excellent technical assistance in the laboratory.

\section{REFERENCES}

Akbar, H., T. M. Grala, M. V. Riboni, F. C. Cardoso, G. Verkerk, J. McGowan, K. Macdonald, J. Webster, K. Schutz, and S. Meier. 2015. Body condition score at calving affects systemic and hepatic transcriptome indicators of inflammation and nutrient metabolism in grazing dairy cows. J. Dairy Sci. 98:1019-1032.

Akter, S. H., S. Haussler, S. Danicke, U. Muller, D. von Soosten, J. Rehage, and H. Sauerwein. 2011. Physiological and conjugated linoleic acid-induced changes of adipocyte size in different fat depots of dairy cows during early lactation. J. Dairy Sci. 94:2871-2882.

Akter, S. H., S. Häussler, D. Germeroth, D. von Soosten, S. Dänicke, K. H. Südekum, and H. Sauerwein. 2012. Immunohistochemical characterization of phagocytic immune cell infiltration into different adipose tissue depots of dairy cows during early lactation. J. Dairy Sci. 95:3032-3044.

Benson, D. A., M. Cavanaugh, K. Clark, I. Karsch-Mizrachi, D. J. Lipman, J. Ostell, and E. W. Sayers. 2013. Genbank. Nucleic Acids Res. 41:D36-D42.

Bernabucci, U., B. Ronchi, N. Lacetera, and A. Nardone. 2005. Influence of body condition score on relationships between metabolic status and oxidative stress in periparturient dairy cows. J. Dairy Sci. 88:2017-2026.

Bradford, B. J., L. K. Mamedova, J. E. Minton, J. S. Drouillard, and B. J. Johnson. 2009. Daily injection of tumor necrosis factor-alpha increases hepatic triglycerides and alters transcript abundance of metabolic genes in lactating dairy cattle. J. Nutr. 139:1451-1456.

Bradford, B. J., K. Yuan, J. K. Farney, L. K. Mamedova, and A. J. Carpenter. 2015. Invited review: Inflammation during the transition to lactation: New adventures with an old flame. J. Dairy Sci. 98:6631-6650.

Carbone, F., C. La Rocca, and G. Matarese. 2012. Immunological functions of leptin and adiponectin. Biochimie 94:2082-2088.

Chen, H., L. Zhang, X. W. Li, X. B. Li, G. Q. Sun, X. Yuan, L. C. Lei, J. X. Liu, L. H. Yin, Q. H. Deng, J. G. Wang, Z. X. Liu, W. T. Yang, Z. Wang, H. Zhang, and G. W. Liu. 2013. Adiponectin activates the ampk signaling pathway to regulate lipid metabolism in bovine hepatocytes. J. Steroid Biochem. Mol. Biol. 138:445-454.

Chilliard, Y., C. Delavaud, and M. Bonnet. 2005. Leptin expression in ruminants: Nutritional and physiological regulations in relation with energy metabolism. Domest. Anim. Endocrinol. 29:3-22.

Cinti, S., G. Mitchell, G. Barbatelli, I. Murano, E. Ceresi, E. Faloia, S. P. Wang, M. Fortier, A. S. Greenberg, and M. S. Obin. 2005. Adipocyte death defines macrophage localization and function in adipose tissue of obese mice and humans. J. Lipid Res. 46:2347-2355.

Contreras, G. A., E. Kabara, J. Brester, L. Neuder, and M. Kiupel. 2015. Macrophage infiltration in the omental and subcutaneous adipose tissues of dairy cows with displaced abomasum. J. Dairy Sci. 98:6176-6187.

Contreras, G. A., C. Strieder-Barboza, and J. De Koster. 2018. Modulating adipose tissue lipolysis and remodeling to improve immune function during the transition period and early lactation of dairy cows. J. Dairy Sci. 101:2737-2752.

Contreras, G. A., C. Strieder-Barboza, and W. Raphael. 2017b. Adipose tissue lipolysis and remodeling during the transition period of dairy cows. J. Anim. Sci. Biotechnol. 8:41-53.

Contreras, G. A., K. Thelen, S. E. Schmidt, C. Strieder-Barboza, C. L. Preseault, W. Raphael, M. Kiupel, J. Caron, and A. L. Lock. 2016. Adipose tissue remodeling in late-lactation dairy cows during feed-restriction-induced negative energy balance. J. Dairy Sci. 99:10009-10021.

Cornier, M. A., D. Dabelea, T. L. Hernandez, R. C. Lindstrom, A. J. Steig, N. R. Stob, R. E. Van Pelt, H. Wang, and R. H. Eckel. 2008. The metabolic syndrome. Endocr. Rev. 29:777-822.

De Koster, J., M. Hostens, M. Van Eetvelde, K. Hermans, S. Moerman, H. Bogaert, E. Depreester, W. Van den Broeck, and G. 
Opsomer. 2015. Insulin response of the glucose and fatty acid metabolism in dry dairy cows across a range of body condition scores. J. Dairy Sci. 98:4580-4592.

De Koster, J., C. Urh, M. Hostens, W. Van den Broeck, H. Sauerwein, and G. Opsomer. 2017. Relationship between serum adiponectin concentration, body condition score, and peripheral tissue insulin response of dairy cows during the dry period. Domest. Anim. Endocrinol. 59:100-104.

Després, J. P., and I. Lemieux. 2006. Abdominal obesity and metabolic syndrome. Nature 444:881-887.

Drackley, J. K. 1999. Biology of dairy cows during the transition period: The final frontier? J. Dairy Sci. 82:2259-2273.

Drackley, J. K., H. M. Dann, G. N. Douglas, N. A. J. Guretzky, N. B. Litherland, J. P. Underwood, and J. J. Loor. 2005. Physiological and pathological adaptations in dairy cows that may increase susceptibility to periparturient diseases and disorders. Ital. J. Anim. Sci. 4:323-344.

Drackley, J. K., S. S. Donkin, and C. K. Reynolds. 2006. Major advances in fundamental dairy cattle nutrition. J. Dairy Sci. 89:1324-1336.

Edmonson, A. J., I. J. Lean, L. D. Weaver, T. Farver, and G. Webster. 1989. A body condition scoring chart for Holstein dairy cows. J. Dairy Sci. 72:68-78.

Erkens, T., M. Van Poucke, J. Vandesompele, K. Goossens, A. Van Zeveren, and L. J. Peelman. 2006. Development of a new set of reference genes for normalization of real-time rt-pcr data of porcine backfat and longissimus dorsi muscle, and evaluation with ppargc1a. BMC Biotechnol. 6:41-48.

Esposito, G., P. C. Irons, E. C. Webb, and A. Chapwanya. 2014. Interactions between negative energy balance, metabolic diseases, uterine health and immune response in transition dairy cows. Anim. Reprod. Sci. 144:60-71.

Goossens, K., M. Van Poucke, A. Van Soom, J. Vandesompele, A. Van Zeveren, and L. J. Peelman. 2005. Selection of reference genes for quantitative real-time pcr in bovine preimplantation embryos. BMC Dev. Biol. 5:27.

Heilbronn, L. K., and L. V. Campbell. 2008. Adipose tissue macrophages, low grade inflammation and insulin resistance in human obesity. Curr. Pharm. Des. 14:1225-1230.

Hood, R. L., and C. E. Allen. 1973. Cellularity of bovine adipose tissue. J. Lipid Res. 14:605-610.

Hotamisligil, G. S. 2006. Inflammation and metabolic disorders. Nature 444:860-867.

Hotamisligil, G. S., P. Arner, J. F. Caro, R. L. Atkinson, and B. M. Spiegelman. 1995. Increased adipose tissue expression of tumor necrosis factor-alpha in human obesity and insulin resistance. J. Clin. Invest. 95:2409-2415.

Ingvartsen, K. L., and Y. R. Boisclair. 2001. Leptin and the regulation of food intake, energy homeostasis and immunity with special focus on periparturient ruminants. Domest. Anim. Endocrinol. $21: 215-250$.

Ji, P., J. K. Drackley, M. J. Khan, and J. J. Loor. 2014a. Inflammation-and lipid metabolism-related gene network expression in visceral and subcutaneous adipose depots of Holstein cows. J. Dairy Sci. 97:3441-3448.

Ji, P., J. K. Drackley, M. J. Khan, and J. J. Loor. 2014b. Overfeeding energy upregulates peroxisome proliferator-activated receptor (ppar)- $\gamma$ controlled adipogenic and lipolytic gene networks but does not affect proinflammatory markers in visceral and subcutaneous adipose depots of Holstein cows. J. Dairy Sci. 97:3431-3440.

Juge-Aubry, C. E., E. Somm, A. Pernin, N. Alizadeh, V. Giusti, J. M. Dayer, and C. A. Meier. 2005. Adipose tissue is a regulated source of interleukin-10. Cytokine 29:270-274.

Kabara, E., L. M. Sordillo, S. Holcombe, and G. A. Contreras. 2014. Adiponectin links adipose tissue function and monocyte inflammatory responses during bovine metabolic stress. Comp. Immunol. Microbiol. Infect. Dis. 37:49-58.

Kadowaki, T., and T. Yamauchi. 2005. Adiponectin and adiponectin receptors. Endocr. Rev. 26:439-451.

Kahn, B. B., and J. S. Flier. 2000. Obesity and insulin resistance. J. Clin. Invest. 106:473-481.
Khan, M. J., A. Hosseini, S. Burrell, S. M. Rocco, J. P. McNamara, and J. J. Loor. 2013. Change in subcutaneous adipose tissue metabolism and gene network expression during the transition period in dairy cows, including differences due to sire genetic merit. J. Dairy Sci. 96:2171-2182.

Lacetera, N., D. Scalia, U. Bernabucci, B. Ronchi, D. Pirazzi, and A. Nardone. 2005. Lymphocyte functions in overconditioned cows around parturition. J. Dairy Sci. 88:2010-2016.

LeBlanc, S. 2010. Monitoring metabolic health of dairy cattle in the transition period. J. Reprod. Dev. 56:S29-S35.

Lemor, A., A. Hosseini, H. Sauerwein, and M. Mielenz. 2009. Transition period-related changes in the abundance of the mrnas of adiponectin and its receptors, of visfatin, and of fatty acid binding receptors in adipose tissue of high-yielding dairy cows. Domest. Anim. Endocrinol. 37:37-44.

Loor, J. J., H. M. Dann, N. A. J. Guretzky, R. E. Everts, R. Oliveira, C. A. Green, N. B. Litherland, S. L. Rodriguez-Zas, H. A. Lewin, and J. K. Drackley. 2006. Plane of nutrition prepartum alters hepatic gene expression and function in dairy cows as assessed by longitudinal transcript and metabolic profiling. Physiol. Genomics 27:29-41.

Loor, J. J., R. E. Everts, M. Bionaz, H. M. Dann, D. E. Morin, R. Oliveira, S. L. Rodriguez-Zas, J. K. Drackley, and H. A. Lewin. 2007. Nutrition-induced ketosis alters metabolic and signaling gene networks in liver of periparturient dairy cows. Physiol. Genomics 32:105-116.

Lumeng, C. N., J. L. Bodzin, and A. R. Saltiel. 2007. Obesity induces a phenotypic switch in adipose tissue macrophage polarization. J. Clin. Invest. 117:175-184.

Martel, C. A., L. K. Mamedova, J. E. Minton, M. L. Jones, J. A. Carroll, and B. J. Bradford. 2014. Continuous low-dose infusion of tumor necrosis factor alpha in adipose tissue elevates adipose tissue interleukin 10 abundance and fails to alter metabolism in lactating dairy cows. J. Dairy Sci. 97:4897-4906.

McArt, J. A. A., D. V. Nydam, G. R. Oetzel, T. R. Overton, and P. A. Ospina. 2013. Elevated non-esterified fatty acids and $\beta$-hydroxybutyrate and their association with transition dairy cow performance. Vet. J. 198:560-570.

McNamara, J. P. 1991. Regulation of adipose tissue metabolism in support of lactation. J. Dairy Sci. 74:706-719.

Moisá, S. J., P. Ji, J. Drackley, S. Rodriguez-Zas, and J. Loor. 2017. Transcriptional changes in mesenteric and subcutaneous adipose tissue from holstein cows in response to plane of dietary energy. J. Anim. Sci. Biotechnol. 8:85.

Morrow, D. A. 1976. Fat cow syndrome. J. Dairy Sci. 59:1625-1629.

O'Boyle, N., C. M. Corl, J. C. Gandy, and L. M. Sordillo. 2006. Relationship of body condition score and oxidant stress to tumor necrosis factor expression in dairy cattle. Vet. Immunol. Immunopathol. 113:297-304.

Ohtsuka, H., M. Koiwa, A. Hatsugaya, K. Kudo, F. Hoshi, N. Itoh, H. Yokota, H. Okada, and S. Kawamura. 2001. Relationship between serum tnf activity and insulin resistance in dairy cows affected with naturally occurring fatty liver. J. Vet. Med. Sci. 63:1021-1025.

Olefsky, J. M., and C. K. Glass. 2010. Macrophages, inflammation, and insulin resistance. Annu. Rev. Physiol. 72:219-246.

Paz-Filho, G., C. Mastronardi, C. B. Franco, K. B. Wang, M.-L. Wong, and J. Licinio. 2012. Leptin: Molecular mechanisms, systemic proinflammatory effects, and clinical implications. Arq. Bras. Endocrinol. Metabol 56:597-607.

Roche, J. R., N. C. Friggens, J. K. Kay, M. W. Fisher, K. J. Stafford, and D. P. Berry. 2009. Invited review: Body condition score and its association with dairy cow productivity, health, and welfare. J. Dairy Sci. 92:5769-5801.

Roche, J. R., J. K. Kay, N. C. Friggens, J. J. Loor, and D. P. Berry. 2013. Assessing and managing body condition score for the prevention of metabolic disease in dairy cows. Vet. Clin. North Am. Food Anim. Pract. 29:323-336.

Saremi, B., H. Sauerwein, S. Dänicke, and M. Mielenz. 2012. Technical note: Identification of reference genes for gene expression studies in different bovine tissues focusing on different fat depots. J. Dairy Sci. 95:3131-3138. 
Saremi, B., S. Winand, P. Friedrichs, A. Kinoshita, J. Rehage, S. Dänicke, S. Häussler, G. Breves, M. Mielenz, and H. Sauerwein. 2014. Longitudinal profiling of the tissue-specific expression of genes related with insulin sensitivity in dairy cows during lactation focusing on different fat depots. PLoS One 9:e86211.

Sindhu, S., R. Thomas, P. Shihab, D. Sriraman, K. Behbehani, and R. Ahmad. 2015. Obesity is a positive modulator of il-6r and il-6 expression in the subcutaneous adipose tissue: Significance for metabolic inflammation. PLoS One 10:e0133494.

Singh, S. P., S. Haussler, J. F. L. Heinz, S. H. Akter, B. Saremi, U. Muller, J. Rehage, S. Danicke, M. Mielenz, and H. Sauerwein. 2014. Lactation driven dynamics of adiponectin supply from different fat depots to circulation in cows. Domest. Anim. Endocrinol. 47:35-46.

Smith, T. R., and J. P. McNamara. 1990. Regulation of bovine adipose tissue metabolism during lactation. 6. Cellularity and hormonesensitive lipase activity as affected by genetic merit and energy intake. J. Dairy Sci. 73:772-783.

Sordillo, L. M. 2016. Nutritional strategies to optimize dairy cattle immunity. J. Dairy Sci. 99:4967-4982.

Sordillo, L. M., and W. Raphael. 2013. Significance of metabolic stress, lipid mobilization, and inflammation on transition cow disorders. Vet. Clin. North Am. Food Anim. Pract. 29:267-278.

Stern, J. H., J. Rutkowski, and P. Scherer. 2016. Adiponectin, leptin, and fatty acids in the maintenance of metabolic homeostasis through adipose tissue crosstalk. Cell Metab. 23:770-784.

Surmi, B. K., and A. H. Hasty. 2008. Macrophage infiltration into adipose tissue: Initiation, propagation and remodeling. Future Lipidol. 3:545-556.
Trevisi, E., M. Amadori, S. Cogrossi, E. Razzuoli, and G. Bertoni. 2012. Metabolic stress and inflammatory response in high-yielding, periparturient dairy cows. Res. Vet. Sci. 93:695-704.

Untergasser, A., H. Nijveen, X. Rao, T. Bisseling, R. Geurts, and J. A. M. Leunissen. 2007. Primer3plus, an enhanced web interface to primer3. Nucleic Acids Res. 35(Suppl. 2):W71-4.

Vailati-Riboni, M., G. Farina, F. Batistel, A. Heiser, M. D. Mitchell, M. A. Crookenden, C. G. Walker, J. K. Kay, S. Meier, J. R. Roche, and J. J. Loor. 2017. Far-off and close-up dry matter intake modulate indicators of immunometabolic adaptations to lactation in subcutaneous adipose tissue of pasture-based transition dairy cows. J. Dairy Sci. 100:2334-2350.

Vailati Riboni, M., S. Meier, N. V. Priest, C. R. Burke, J. K. Kay, S. McDougall, M. D. Mitchell, C. G. Walker, M. Crookenden, A. Heiser, J. R. Roche, and J. J. Loor. 2015. Adipose and liver gene expression profiles in response to treatment with a nonsteroidal antiinflammatory drug after calving in grazing dairy cows. J. Dairy Sci. 98:3079-3085.

Vandesompele, J., K. De Preter, F. Pattyn, B. Poppe, N. Van Roy, A. De Paepe, and F. Speleman. 2002. Accurate normalization of realtime quantitative rt-pcr data by geometric averaging of multiple internal control genes. Genome Biol. 3:H0034.

Yamauchi, T., and T. Kadowaki. 2008. Physiological and pathophysiological roles of adiponectin and adiponectin receptors in the integrated regulation of metabolic and cardiovascular diseases. Int. J. Obes. (Lond.) 32:S13-S18.

Zuker, M. 2003. Mfold web server for nucleic acid folding and hybridization prediction. Nucleic Acids Res. 31:3406-3415. 